\title{
AGRO-MORPHOLOGICAL AND FORAGE QUALITY TRAITS OF SELECTED ALFALFA POPULATIONS AND THEIR APPLICATION IN BREEDING
}

\author{
Marijana TUCAK ${ }^{1 *}$, Svetislav POPOVIĆ ${ }^{1}$, Tihomir $\check{C} U P I C^{l}$, Goran KRIZMANIĆ ${ }^{1}$, Valentina $\check{S} P A N I C^{l}$, \\ Branimir $\check{S I M I C ́}^{l}$, Vladimir MEGLIČ ${ }^{2}$ \\ ${ }^{I}$ Agricultural Institute Osijek, Juzno predgradje, Osijek, CROATIA \\ ${ }^{2}$ Agricultural Institute of Slovenia, Hacquetova, Ljubljana, SLOVENIA \\ *Corresponding author: marijana.tucak@poljinos.hr
}

Received: 23.10 .2013

\begin{abstract}
The objectives of this research were to evaluate agro-morphological and forage quality performances of selected alfalfa populations and to predict the genetic potential of this populations as a source of the material for breeding programs and/or commercial use. Twenty selected alfalfa populations and two control cultivars were tested over three consecutive years $(2008,2009,2010)$ at the experimental field of the Agricultural Institute Osijek in Croatia. The experimental design was a randomized complete block with three replications. The plot size was $6 \mathrm{~m}^{2}$ at the sowing rate of $15 \mathrm{~kg} \mathrm{ha}^{-1}$. A total of fifteen traits were measured/analysed on all plots and/or individual plants of all populations and cultivars. Significant differences were determined between alfalfa populations/cultivars in all investigated traits, except for content of crude protein in dry matter. The highest three-years average yields (from 86.32 to $101.12 \mathrm{t} \mathrm{ha}^{-1}$ for green mass, from 17.45 to $20.46 \mathrm{t}$ $\mathrm{ha}^{-1}$ for dry matter, from 3657 to $4289 \mathrm{~kg} \mathrm{ha}^{-1}$ for crude protein) and favourable values for the most of the investigated morphological and forage quality traits were obtained in populations MSP 16,8,1,9,20,11,10. Seven superior alfalfa populations were identified which could represent a valuable source of genetic material for further selection and improvement of our breeding program and/or application for plant cultivar registration.
\end{abstract}

Keywords: Alfalfa, agro-morphological traits, breeding, forage quality, population

\section{INTRODUCTION}

Alfalfa is one of the most widely cultivated forage legumes, that is cut off for hay and silage and/or growth in pasture for grazing, in the world because of its high nutritional quality for livestock, high biomass production, broad adaptability to a wide range of ecological conditions and a favourable environmental impact (Herrmann et al., 2010; Bouton, 2012; Sabanci et al., 2013). Alfalfa breeding programs are mainly focused on yield increasing, enhancing forage nutritive value and improving of tolerance to abiotic/biotic stresses. Alfalfa is perennial species with highly genetic complexity at individual and population level due to its autotetraploidy and allogamy that is characterized by a high level of heterozygosity and severe inbreeding depression (Labombarda et al., 2000; Tucak et al., 2010). Currently, in most commercial alfalfa breeding programs, most used methods for the development of alfalfa cultivars is recurrent phenotypic selection, with or without progeny testing, with tendency to accumulate desirable alleles at high frequency into a population (Li and Brummer, 2012). Development of new alfalfa cultivars and/or populations is difficult and a very long-lasting process in which mainly is evaluated all the available germplasm of large number individual plants in nursery over multiple cuttings per year and multiple years. In each of several cycles of selection the superior plants have been selected and intercrossed to generate new populations with improved important agronomic traits (insects/diseases resistance, cold/drought tolerance, greater persistence, higher forage yield and nutritional value). After several cycles of selection, alfalfa breeders could increase the frequency of favorable individuals of important agronomic traits but it can be difficult to know if the original genetic diversity present in the breeding pool was maintained and/or increased/decreased.

Constantly maintenance genetic diversity and variability of alfalfa breeding pool during the selection through introductions of distances materials as a new source of genetic diversity is a prerequisite for successful breeding and developing of new cultivars/populations with high potential for yield and forage quality (Tucak et al., 2011; Živković et al., 2012).

The objectives of this research were to evaluate agromorphological and forage quality performances of 
selected alfalfa populations and to predict the genetic potential of this populations as a source of the material for breeding programs and/or commercial use.

\section{MATERIALS AND METHODS}

Twenty selected alfalfa populations (MSP1 to MSP20) and two control cultivars (OS-88, OS-99) were tested over three consecutive years $(2008,2009,2010)$ at the experimental field of the Agricultural Institute Osijek in Croatia. Investigated populations were developed after four cycles of phenotypic selection from breeding nurseries which contained diverse alfalfa germplasm in which superior individual plants have been selected for higher green mass yield and persistency. The field trial was established (17/03 in 2008) as randomized block design with three replications. The plot size was $6 \mathrm{~m}^{2}$. Hand sowing was done at row distance of $20 \mathrm{~cm}$ at the sowing rate of $15 \mathrm{~kg} \mathrm{ha}^{-1}$. The experimental plots were cut four times in the first growing season (23/06, 30/07, 28/08, 27/10 in 2008) and five times in the second and third growing seasons $(05 / 05,04 / 06,07 / 07,13 / 08,18 / 09$ in $2009,11 / 05,12 / 06,13 / 07,15 / 08,25 / 10$ in 2010). At each cut in all growing seasons yields of green mass, dry matter and crude protein (GMY, DMY, CPY) per plot, height and regeneration of plants (PH, PR, average on five randomly selected plants/plots, $\mathrm{cm}$ ) were measured. Yields were expressed as the average annual yield in investigated three-year experiments in $\mathrm{t} \mathrm{ha}^{-1}$ for GMY and DMY, respectively, and in $\mathrm{kg} \mathrm{ha}^{-1}$ for CPY. In second cut of the second growing season, using the ten randomly selected stems of all plots of each population/cultivar, number and length of internodes (NI and LI, mm) stem thickness (ST, mm) and width and length of central leaflet (WCL and LCL, mm) were determined. In the same cut, forage samples of $1 \mathrm{~kg}$ were randomly taken from the middle rows from each plot of all populations/cultivars for leaf to stem ratio (LSR) and forage quality traits determination. The content of crude protein $(\mathrm{CP})$ and neutral and acid detergente fiber (NDF, ADF) in dry matter were determined according to standard methods (AOAC, 1995). Relative feed value (RFV) was calculated according to equations adapted from common formulas for forages (Schroeder, 1994). All collected data were processed by analyses of variance applying the least significant differences test using the general linear model procedure of SAS software 9.1.3 (SAS Institute, 20022003).

\section{RESULTS AND DISCUSSION}

Significant differences were determined between alfalfa populations/cultivars in all investigated traits, except for content of crude protein in dry matter (Tables 1 and 2, Figure $1 \mathrm{AB})$.

Table 1. Average values of the investigated agronomical traits of 22 alfalfa populations/ cultivars, 2008-2010, Agricultural institute Osijek

\begin{tabular}{|c|c|c|c|c|c|}
\hline \multirow{2}{*}{$\begin{array}{l}\text { Populations/ } \\
\text { cultivars }\end{array}$} & \multicolumn{5}{|c|}{ Investigated traits } \\
\hline & *GMY $\left(\mathbf{t ~ h a}^{-1}\right)$ & DMY (t ha $\left.{ }^{-1}\right)$ & CPY $\left(\mathrm{kg} \mathrm{ha}^{-1}\right)$ & PH (cm) & PR (cm) \\
\hline MSP1 & $92.21^{\mathrm{BC}}$ & $18.60^{\mathrm{BC}}$ & $3774^{\mathrm{ABC}}$ & $79.39^{\mathrm{A}}$ & $24.26^{\mathrm{ABC}}$ \\
\hline MSP2 & $75.60^{\mathrm{IJK}}$ & $15.61^{\mathrm{FGH}}$ & $3206^{C-G}$ & $74.85^{\mathrm{B}-\mathrm{G}}$ & $17.49^{\mathrm{IJ}}$ \\
\hline MSP3 & $75.03^{\mathrm{IJK}}$ & $15.85^{\mathrm{FGH}}$ & $3274^{C-G}$ & $74.71^{\mathrm{B}-\mathrm{G}}$ & $19.23^{\mathrm{F}-\mathrm{J}}$ \\
\hline MSP4 & $79.90^{\mathrm{F}-\mathrm{K}}$ & $16.45^{\mathrm{E}-\mathrm{H}}$ & $3458^{\mathrm{C}-\mathrm{G}}$ & $72.39^{\mathrm{F}-\mathrm{I}}$ & $20.47^{\mathrm{D}-\mathrm{H}}$ \\
\hline MSP5 & $81.38^{\mathrm{E}-\mathrm{K}}$ & $16.59^{\mathrm{D}-\mathrm{H}}$ & $3338^{\mathrm{C}-\mathrm{G}}$ & $71.37^{\mathrm{GHI}}$ & $19.23^{\mathrm{F}-\mathrm{J}}$ \\
\hline MSP6 & $80.34^{\mathrm{E}-\mathrm{K}}$ & $16.54^{\text {E-H }}$ & $3351^{\mathrm{C}-\mathrm{G}}$ & $72.90^{\mathrm{E}-\mathrm{I}}$ & $17.06^{\mathrm{IJ}}$ \\
\hline MSP7 & $83.04^{\mathrm{D}-\mathrm{J}}$ & $17.18^{\mathrm{C}-\mathrm{F}}$ & $3460^{C-G}$ & $73.73^{\mathrm{D}-\mathrm{I}}$ & $19.52^{\mathrm{F}-\mathrm{J}}$ \\
\hline MSP8 & $98.71^{\mathrm{AB}}$ & $19.34^{\mathrm{AB}}$ & $4151^{\mathrm{AB}}$ & $78.28^{\mathrm{AB}}$ & $22.71^{\mathrm{CDE}}$ \\
\hline MSP9 & $90.25^{\mathrm{BCD}}$ & $18.43^{\mathrm{BCD}}$ & $3722^{\mathrm{ABC}}$ & $77.87^{\mathrm{ABC}}$ & $26.01^{\mathrm{AB}}$ \\
\hline MSP10 & $86.32^{\mathrm{C}-\mathrm{G}}$ & $18.08^{\mathrm{B}-\mathrm{E}}$ & $3690^{\mathrm{BCD}}$ & $74.93^{\mathrm{B}-\mathrm{G}}$ & $23.28^{\mathrm{BCD}}$ \\
\hline MSP11 & $88.34^{\mathrm{C}-\mathrm{F}}$ & $17.94^{\mathrm{B}-\mathrm{E}}$ & $3707^{\mathrm{A}-\mathrm{D}}$ & $76.09^{\mathrm{A}-\mathrm{F}}$ & $22.03^{\mathrm{C}-\mathrm{F}}$ \\
\hline MSP12 & $78.14^{\mathrm{G}-\mathrm{K}}$ & $16.34^{\mathrm{E}-\mathrm{H}}$ & $3599^{\mathrm{B}-\mathrm{F}}$ & $71.60^{\mathrm{GHI}}$ & $17.35^{\mathrm{IJ}}$ \\
\hline MSP13 & $74.50^{\mathrm{JK}}$ & $15.07^{\mathrm{H}}$ & $2961^{\mathrm{G}}$ & $70.01^{\mathrm{HIJ}}$ & $17.21^{\mathrm{IJ}}$ \\
\hline MSP14 & $73.93^{\mathrm{K}}$ & $15.29^{\mathrm{GH}}$ & $3131^{\mathrm{D}-\mathrm{G}}$ & $66.77^{\mathrm{J}}$ & $16.74^{\mathrm{J}}$ \\
\hline MSP15 & $76.63^{\mathrm{H}-\mathrm{K}}$ & $15.22^{\mathrm{GH}}$ & $3060^{\mathrm{FG}}$ & $71.71^{\mathrm{GHI}}$ & $18.68^{\mathrm{G}-\mathrm{J}}$ \\
\hline MSP16 & $101.12^{\mathrm{A}}$ & $20.46^{\mathrm{A}}$ & $4289^{\mathrm{A}}$ & $76.84^{\mathrm{A}-\mathrm{E}}$ & $26.56^{\mathrm{A}}$ \\
\hline MSP17 & $85.18^{\mathrm{C}-\mathrm{H}}$ & $17.30^{\mathrm{C}-\mathrm{F}}$ & $3575^{\mathrm{B}-\mathrm{F}}$ & $69.69^{\mathrm{IJ}}$ & $18.76^{\mathrm{G}-\mathrm{J}}$ \\
\hline MSP18 & $83.81^{\mathrm{C}-\mathrm{I}}$ & $16.89^{\mathrm{C}-\mathrm{H}}$ & $3553^{\mathrm{C}-\mathrm{F}}$ & $74.04^{\mathrm{C}-\mathrm{H}}$ & $20.63^{\mathrm{D}-\mathrm{H}}$ \\
\hline MSP19 & $85.80^{\mathrm{C}-\mathrm{G}}$ & $17.01^{\mathrm{C}-\mathrm{G}}$ & $3405^{\mathrm{C}-\mathrm{G}}$ & $70.57^{\mathrm{HIJ}}$ & $17.91^{\mathrm{HIJ}}$ \\
\hline MSP20 & $89.06^{\mathrm{CDE}}$ & $17.45^{\mathrm{C}-\mathrm{F}}$ & $3657^{\mathrm{B}-\mathrm{E}}$ & $77.26^{\mathrm{A}-\mathrm{D}}$ & $21.22^{\mathrm{D}-\mathrm{G}}$ \\
\hline OS-88 & $83.39^{\mathrm{C}-\mathrm{I}}$ & $16.93^{\mathrm{C}-\mathrm{G}}$ & $3589^{\mathrm{B}-\mathrm{F}}$ & $71.95^{\mathrm{GHI}}$ & $19.81^{\mathrm{E}-\mathrm{I}}$ \\
\hline OS-99 & $76.40^{\mathrm{H}-\mathrm{K}}$ & $15.96^{\mathrm{FGH}}$ & $3091^{\mathrm{EFG}}$ & $73.55^{\mathrm{D}-\mathrm{I}}$ & $17.49^{\mathrm{IJ}}$ \\
\hline Average & 83.59 & 17.02 & 3502 & 73.66 & 20.17 \\
\hline $\mathrm{CV}(\%)$ & 4.80 & 4.93 & 7.62 & 2.53 & 6.56 \\
\hline LSD 0.05 & 6.62 & 1.38 & 440.12 & 3.07 & 2.18 \\
\hline LSD 0.01 & 8.85 & 1.85 & 588.41 & 4.10 & 2.91 \\
\hline
\end{tabular}

Values within columns followed by different letter are significantly different at the $P \leq 0.01$

*GMY-green mass yield; DMY-dry matter yield; CPY-crude protein yield; PH-plant height; PR-plant regeneration 
Population MSP 16 had significantly the highest threeyear average yields of green mass, dry matter and crude protein (101.12 $\mathrm{t} \mathrm{ha}^{-1}$ GMY, $20.46 \mathrm{t} \mathrm{ha}^{-1}$ DMY, $4289 \mathrm{~kg}$ $\left.\mathrm{ha}^{-1} \mathrm{CPY}\right)$. This population had higher yields than control cultivars (for GMY up to $24.44 \%$, for DMY up to 21.99 $\%$, for CPY up to $27.93 \%$ in comparison to cultivar OS99). Also this population was superior above mean values of all populations/cultivars (for GMY up to $17.33 \%$, for DMY up to $16.81 \%$ and for CPY up to $18.34 \%$ ). High yields were determined for populations MSP 8,1,9,20,11,10 (Table 1).

Significant reduction in yield had population MSP 14 and 13. Dry matter yields obtained in this study were similar to results obtained by Avci et al. (2010) who examined the performances of phenotypically superior alfalfa lines. Our results were lower than the yields obtained from Annicchiarico et al. (2011) who studied the landraces and cultivars of different geographical origin across ten different agricultural environments.

Besides the different genetic yield potential of alfalfa materials included in these investigations, the yield differences were most likely associated with different environmental conditions where tests were conducted. The average plant height ranged from $66.77 \mathrm{~cm}$ (MSP 14) to $79.39 \mathrm{~cm}$ (MSP 1), which was similar to the results of Rimi et al. (2010) who obtained a range of plant heights from $65.9 \mathrm{~cm}$ to $75.0 \mathrm{~cm}$. The fastest growth was recorded after cuts in population MSP $16(26.56 \mathrm{~cm})$, which was not significantly faster than the values determined regeneration in populations MSP 9 and 1 (Table 1). Population MSP 18 had the highest number of internodes per stem (12.10), which was not significantly higher than the values obtained in populations MSP 9,11,16,2,7,10,5 (Table 2). Length of internodes per stem ranged from $32.30 \mathrm{~mm}$ (MSP 4) to $44.00 \mathrm{~mm}$ (MSP 17). According to Annicchiarico et al. (2010) forage quality can be improved by selection for modified stem morphology (increased internode number, decreased internode length). This statement is confirmed by the results achieved by population MSP 11, which had a larger number of shorter internodes, the best leaf to stem ratio (1.011, Table 2), satisfying protein content, low content of NDF and ADF and therefore the highest relative feed value (160.26, Figure $1 \mathrm{AB}$ ). According to quality standards (Hay Marketing Task Force of the American forage and Grassland Council, RFV > 151) it was classified in the category of high-quality forage.

Table 2. Average values of the investigated morphological traits of 22 alfalfa populations/ cultivars in the second cut of the second growing season, 2009, Agricultural institute Osijek

\begin{tabular}{|c|c|c|c|c|c|c|}
\hline \multirow{2}{*}{$\begin{array}{l}\text { Populations/ } \\
\text { cultivars }\end{array}$} & \multicolumn{5}{|c|}{ Investigated traits } & \multirow[b]{2}{*}{ LSR } \\
\hline & $* \mathbf{N I}$ & LI (mm) & ST (mm) & WCL (mm) & LCL (mm) & \\
\hline MSP1 & $10.90^{\mathrm{C}-\mathrm{F}}$ & $42.00^{\mathrm{AB}}$ & $2.19^{\mathrm{A}-\mathrm{D}}$ & $10.60^{\mathrm{E}}$ & $30.00^{\mathrm{BCD}}$ & $0.965^{\mathrm{AB}}$ \\
\hline MSP2 & $11.40^{\mathrm{ABC}}$ & $35.80^{\mathrm{B}-\mathrm{F}}$ & $2.21^{\mathrm{A}-\mathrm{D}}$ & $12.80^{\mathrm{AB}}$ & $30.40^{\mathrm{ABC}}$ & $0.879^{\mathrm{FGH}}$ \\
\hline MSP3 & $10.70^{\mathrm{C}-\mathrm{F}}$ & $38.60^{\mathrm{A}-\mathrm{F}}$ & $2.20^{\mathrm{A}-\mathrm{D}}$ & $13.20^{\mathrm{A}}$ & $32.50^{\mathrm{A}}$ & $0.869^{\mathrm{GH}}$ \\
\hline MSP4 & $10.40^{\mathrm{EF}}$ & $32.30^{\mathrm{F}}$ & $1.95^{\mathrm{DEF}}$ & $12.00^{\mathrm{A}-\mathrm{E}}$ & $31.30^{\mathrm{AB}}$ & $0.871^{\mathrm{GH}}$ \\
\hline MSP5 & $11.30^{\mathrm{A}-\mathrm{D}}$ & $38.30^{\mathrm{A}-\mathrm{F}}$ & $2.18^{\mathrm{A}-\mathrm{D}}$ & $13.00^{\mathrm{A}}$ & $30.50^{\mathrm{AB}}$ & $0.898^{\mathrm{D}-\mathrm{G}}$ \\
\hline MSP6 & $10.30^{\mathrm{F}}$ & $40.70^{\mathrm{A}-\mathrm{D}}$ & $2.28^{\mathrm{AB}}$ & $12.80^{\mathrm{AB}}$ & $31.10^{\mathrm{AB}}$ & $0.894^{\mathrm{D}-\mathrm{G}}$ \\
\hline MSP7 & $11.40^{\mathrm{ABC}}$ & $41.50^{\mathrm{ABC}}$ & $2.25^{\mathrm{ABC}}$ & $12.30^{\mathrm{A}-\mathrm{E}}$ & $30.70^{\mathrm{AB}}$ & $0.890^{\mathrm{EFG}}$ \\
\hline MSP8 & $11.00^{\mathrm{C}-\mathrm{F}}$ & $34.00^{\mathrm{DEF}}$ & $2.09^{\mathrm{A}-\mathrm{E}}$ & $13.00^{\mathrm{A}}$ & $30.60^{\mathrm{AB}}$ & $0.955^{\mathrm{BC}}$ \\
\hline MSP9 & $11.90^{\mathrm{AB}}$ & $33.10^{\mathrm{EF}}$ & $2.24^{\mathrm{ABC}}$ & $13.00^{\mathrm{A}}$ & $30.50^{\mathrm{AB}}$ & $0.896^{\mathrm{D}-\mathrm{G}}$ \\
\hline MSP10 & $11.30^{\mathrm{A}-\mathrm{D}}$ & $39.20^{\mathrm{A}-\mathrm{F}}$ & $2.05^{\mathrm{A}-\mathrm{F}}$ & $12.80^{\mathrm{AB}}$ & $29.70^{\mathrm{BCD}}$ & $0.913^{\mathrm{B}-\mathrm{G}}$ \\
\hline MSP11 & $11.90^{\mathrm{AB}}$ & $34.70^{\mathrm{C}-\mathrm{F}}$ & $2.05^{\mathrm{A}-\mathrm{F}}$ & $11.80^{\mathrm{A}-\mathrm{E}}$ & $26.30^{\mathrm{FG}}$ & $1.011^{\mathrm{A}}$ \\
\hline MSP12 & $10.80^{\mathrm{C}-\mathrm{F}}$ & $35.20^{\mathrm{B}-\mathrm{F}}$ & $2.18^{\mathrm{A}-\mathrm{D}}$ & $11.70^{\mathrm{A}-\mathrm{E}}$ & $28.10^{\mathrm{C}-\mathrm{F}}$ & $0.897^{\mathrm{D}-\mathrm{G}}$ \\
\hline MSP13 & $11.20^{\mathrm{B}-\mathrm{E}}$ & $35.30^{\mathrm{B}-\mathrm{F}}$ & $2.04^{\mathrm{A}-\mathrm{F}}$ & $11.10^{\mathrm{B}-\mathrm{E}}$ & $26.80^{\mathrm{FG}}$ & $0.929^{\mathrm{B}-\mathrm{F}}$ \\
\hline MSP14 & $11.00^{\mathrm{C}-\mathrm{F}}$ & $34.40^{\mathrm{C}-\mathrm{F}}$ & $2.30^{\mathrm{A}}$ & $11.80^{\mathrm{A}-\mathrm{E}}$ & $29.30^{\mathrm{B}-\mathrm{E}}$ & $0.880^{\mathrm{FGH}}$ \\
\hline MSP15 & $10.50^{\mathrm{DEF}}$ & $41.20^{\mathrm{A}-\mathrm{D}}$ & $2.01^{\mathrm{B}-\mathrm{F}}$ & $12.70^{\mathrm{ABC}}$ & $26.70^{\mathrm{FG}}$ & $0.897^{\mathrm{D}-\mathrm{G}}$ \\
\hline MSP16 & $11.50^{\mathrm{ABC}}$ & $39.90^{\mathrm{A}-\mathrm{E}}$ & $2.01^{\mathrm{B}-\mathrm{F}}$ & $12.00^{\mathrm{A}-\mathrm{E}}$ & $25.70^{\mathrm{GH}}$ & $0.956^{\mathrm{B}}$ \\
\hline MSP17 & $10.50^{\mathrm{DEF}}$ & $44.00^{\mathrm{A}}$ & $1.99^{\mathrm{C}-\mathrm{F}}$ & $11.80^{\mathrm{A}-\mathrm{E}}$ & $27.70^{\mathrm{D}-\mathrm{G}}$ & $0.916^{\mathrm{B}-\mathrm{G}}$ \\
\hline MSP18 & $12.10^{\mathrm{A}}$ & $34.70^{\mathrm{C}-\mathrm{F}}$ & $1.86^{\mathrm{EF}}$ & $10.90^{\mathrm{DE}}$ & $27.10^{\mathrm{EFG}}$ & $0.938^{\mathrm{B}-\mathrm{E}}$ \\
\hline MSP19 & $11.00^{\mathrm{C}-\mathrm{F}}$ & $38.80^{\mathrm{A}-\mathrm{F}}$ & $1.88^{\mathrm{EF}}$ & $12.40^{\mathrm{A}-\mathrm{D}}$ & $29.60^{\mathrm{BCD}}$ & $0.945^{\mathrm{BCD}}$ \\
\hline MSP20 & $10.90^{\mathrm{C}-\mathrm{F}}$ & $39.90^{\mathrm{A}-\mathrm{E}}$ & $1.99^{\mathrm{C}-\mathrm{F}}$ & $12.60^{\mathrm{A}-\mathrm{D}}$ & $23.80^{\mathrm{H}}$ & $0.960^{\mathrm{AB}}$ \\
\hline OS -88 & $11.10^{\mathrm{B}-\mathrm{F}}$ & $32.90^{\mathrm{EF}}$ & $2.04^{\mathrm{A}-\mathrm{F}}$ & $11.00^{\mathrm{CDE}}$ & $27.20^{\mathrm{EFG}}$ & $0.836^{\mathrm{H}}$ \\
\hline OS-99 & $10.70^{\mathrm{C}-\mathrm{F}}$ & $35.20^{\mathrm{B}-\mathrm{F}}$ & $1.79^{\mathrm{F}}$ & $12.70^{\mathrm{ABC}}$ & $29.70^{\mathrm{BCD}}$ & $0.903^{\mathrm{C}-\mathrm{G}}$ \\
\hline Average & 11.08 & 37.35 & 2.08 & 12.18 & 28.87 & 0.914 \\
\hline $\mathrm{CV}(\%)$ & 3.45 & 8.86 & 6.08 & 6.43 & 3.61 & 2.61 \\
\hline LSD 0.05 & 0.630 & 5.45 & 0.208 & 1.29 & 1.72 & 0.039 \\
\hline LSD 0.01 & 0.842 & 7.29 & 0.279 & 1.72 & 2.30 & 0.052 \\
\hline
\end{tabular}



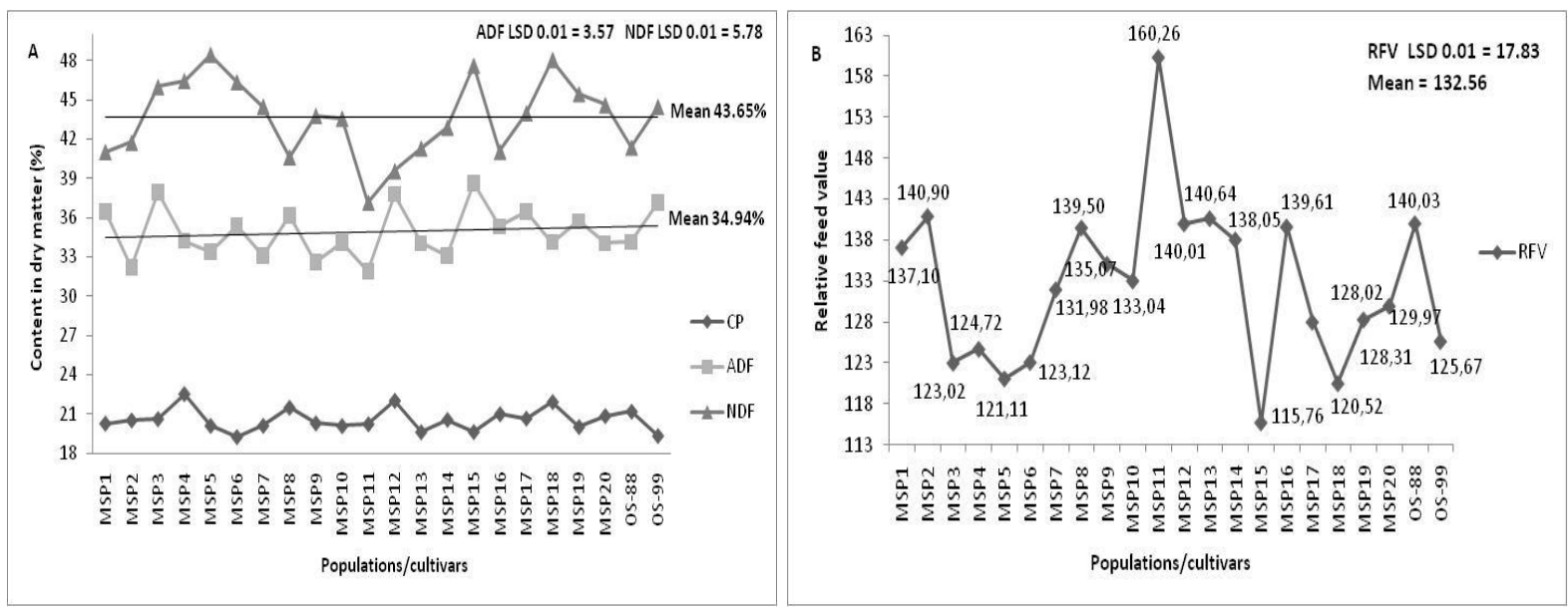

Figure $1 \mathrm{AB}$. Forage quality traits of the investigated of 22 alfalfa populations/cultivars $(\mathrm{CP}-$ crude protein, NDF - neutral detergent fibre, ADF - acid detergent fibre, RFV - relative feed value)

The average thickness of the stems of all populations/cultivars was $2.08 \mathrm{~mm}$, and ranged from 1.79 mm (cultivar OS-99) to $2.30 \mathrm{~mm}$ (population MSP 14).Greatest width and length of central leaflet was found in the population MSP 3 (13.20 and $32.50 \mathrm{~mm}$ ), while the populations MSP 20 and 1 had smallest values of these properties (Table 2). The best leaf to stem ratio had population MSP 11, which was not statistically significantly better than the values of this ratio observed in populations MSP 1 and 20. Population MSP 4 had the highest protein content $(22.53 \%)$, which was not significantly higher compared to all other observed populations/cultivars where the protein content varied from $19.27 \%$ (MSP 16) to $22.02 \%$ (MSP 12). Populations MSP 5 and 15 had the highest content of neutral and acidic fiber and low protein content, which resulted in lower values of RFVs of these populations (Figure $1 \mathrm{AB}$ ). Population MSP 11 had justifiably highest RFV value. High values of RFV were also found in populations MSP 2 and 12. The highest yields and favorable values for the most of the investigated morphological and forage quality traits were obtained at populations MSP 16,8,1,9,20,11,10. These populations represent a valuable source of genetic material for further selection and improvement of our breeding program and/or application for plant cultivar registration.

\section{CONCLUSIONS}

The highest three-years average yields (from 86.32 to $101.12 \mathrm{t} \mathrm{ha}^{-1}$ for green mass, from 17.45 to $20.46 \mathrm{t} \mathrm{ha}^{-1}$ for dry matter, from 3657 to $4289 \mathrm{~kg} \mathrm{ha}^{-1}$ for crude protein) and favourable values for the most of the investigated morphological and forage quality traits were obtained in populations MSP 16,8,1,9,20,11,10. Seven superior alfalfa populations were identified which could represent a valuable source of genetic material for further selection and improvement of our breeding program and/or application for plant cultivar registration.

\section{ACKNOWLEDGMENTS}

This research was supported by the Ministry of Science, Education and Sport of the Republic of Croatia ("Evaluation of breeding value in alfalfa (Medicago spp.) germplasm - No. 073-0000000-3535) and bilateral project (Croatia-Slovenia) "Importance and role of forage legumes in sustainable agriculture and in the environment preservation".

\section{LITERATURE CITED}

Annicchiarico, P., C. Scotti, M. Carelli, L. Pecetti. 2010. Questions and avenues for lucerne improvement. Czech. J. Plant Breed. 46:1-13.

Annicchiarico, P., L. Pecetti, A. Abdelguerfi, A. Bouizgaren, A. M. Carroni, T. Hayek, M. MHammadi Bouzina, M. Mezni. 2011. Adaptation of landrace and variety germplasm and selection strategies for lucerne in the Mediterranean basin. Field Crops Research 120:283-291.

AOAC. 1995. Official methods of analysis. Association of Official Analytical Chemists International, Arlington, VA.

Avci, M., S. Cinar, C. Yucel, I. Ilker. 2010. Evaluation of some selected alfalfa (Medicago sativa $\mathrm{L}$.) lines for herbage yield and forage quality. Journal of Food, Agriculture and Environment 8:545-549.

Bouton, J. H. 2012. Breeding lucerne for persistence. Crop and Pasture Science 63:95-106.

Herrmann, D., S. Flajoulot, B. Julier. 2010. Sample size for diversity studies in tetraploid alfalfa (Medicago sativa) based on codominantly coded SSR markers. Euphytica 171:441446.

Labombarda, P., F. Pupilli, S. Arcioni. 2000. Optimal population size for RFLP- assisted cultivar identification in alfalfa (Medicago sativa L.). Agronomie 20:233-240.

Li, X., E. C. Brummer. 2012. Applied genetics and genomics in alfalfa breeding. Agronomy 2:40-61.

Rimi, F., S. Macolino, B. Leinauer, L. M. Lauriault, U. Ziliotto. 2010. Alfalfa yield and morphology of three fall-dormancy categories harvested at two phenological stages in a subtropical climate. Agronomy Journal 102:1578-1585.

Sabanci, C. O., M. M. Ertus, S. Zorer Celebi. 2013. Collection, conservation and evaluation for forage yield of alfalfa landraces grown in East Anatolia. Turk J Field Crops 18(1):46-51. 
SAS Institute Inc, 2002-2003. SAS/STAT Software, Ver. 9.1.3. Tucak, M., S. Popović, S. Grljušić, T. Čupić, S. Bolarić. 2011. SAS Institute, Cary, NC.

Schroeder, J. W. 1994. Interpreting forage analysis. North Dakota State University Agriculture. Retried from http://www.ag.ndsu.edu/pubs/plantsci/hay/r1080w.htm

Tucak, M., S. Popović, T. Čupić, S. Grljušić, V. Meglič, Z. Jurković. 2010. Efficiency of phenotypic and DNA markers for a genetic diversity study of alfalfa. Russian Journal of Genetics 46(11):1314-1319. Implementation of molecular markers diversity in parental selection of alfalfa (Medicago sativa L.). Biotechnology and Biotechnological Equipment 25:2310-2314.

Živković, B., J. Radović, D. Sokolović, B. Siler, T. Banjanac, R. Štrbanović. 2012. Assessment of genetic diversity among alfalfa (Medicago sativa L.) genotypes by morphometry, seed storage proteins and RAPD analysis. Industrial Crops and Products 40:285-291. 